\title{
Human Colony-forming Units-Erythroid Do Not Require Accessory Cells, but Do Require Direct Interaction with Insulin-like Growth Factor I and/or Insulin for Erythroid Development
}

K. Sawada, S. B. Krantz, E. N. Dessypris, S. T. Koury, and S. T. Sawyer

Department of Medicine, Vanderbilt University School of Medicine and Veterans Administration Medical Center,

Nashville, Tennessee 37232

\begin{abstract}
The presence of heterogeneous erythroid progenitor cells, contaminant cells, or serum may alter erythroid colony development in vitro. To obtain highly purified colony-forming unitserythroid (CFU-E), we cultured partially purified human blood burst-forming units-erythroid (BFU-E) in methylcellulose with recombinant human erythropoietin (rHuEPO) for $7 \mathrm{~d}$ and generated cells that consisted of 30-60\% CFU-E, but no BFU-E. A serum-free medium was used that allowed development of the same number of erythroid colonies as serum containing medium, but with a greater percentage of larger colonies. This medium consisted of delipidated crystalline bovine serum albumin, iron saturated transferrin, lipid suspension, fibrinogen, thrombin, Iscove's modified Dulbecco's medium/F-12[HAM], and insulin plus rHuEPO. When CFU-E were cultured in a limiting dilution assay and the percentage of nonresponder wells was plotted against cell concentration, both serum-free cultures and serum-containing cultures yielded overlapping straight lines through the origin indicating that CFU-E development did not depend on accessory cells and that insulin acted directly on the CFU-E. Human recombinant interleukin 3 (IL-3) and/or granulocyte-macrophage colony-stimulating factor had no effect on CFU-E growth, while they markedly enhanced BFU-E growth. Physiological concentrations of recombinant human insulin-like growth factor I (IGF-I) enhanced CFU-E growth in the absence of insulin and, together with rHuEPO in serum-free medium, provided a plating efficiency equal to that of serum-containing medium. Limiting dilution analysis in serum-free medium with IGF-I showed a straight line through the origin indicating that IGF-I also acted directly on the CFU-E and not through an effect on accessory cells. These data demonstrate that CFU-E do not require accessory cells, but do require IGF-I and/or insulin which act directly on the CFU-E.
\end{abstract}

\section{Introduction}

Knowledge of the specific requirements for the growth and development of colony-forming units-erythroid (CFU-E) ${ }^{1}$ has

This work was presented in part at the annual meeting of the Southern Society for Clinical Investigation, February 1988 (1988. Clin. Res. 36:37a).

Address reprint requests to Dr. Krantz, Department of Medicine (Hematology), Vanderbilt Medical Center North C3101, Nashville, TN 37232.

Received for publication 11 May 1988 and in revised form 27 October 1988.

1. Abbreviations used in this paper: BFU-E, burst forming units-erythroid; BM, bone marrow; CFU-E, colony-forming units-erythroid;

J. Clin. Invest.

(C) The American Society for Clinical Investigation, Inc.

0021-9738/89/05/1701/09 \$2.00

Volume 83, May 1989, 1701-1709 been very limited up to the present time. Iscove et al. (1) described a serum-free medium containing delipidated albumin, iron-saturated transferrin, and a mixture of an unsaturated fatty acid, lecithin and cholesterol, that supports murine CFU-E development, but not burst-forming units-erythroid (BFU-E). Other investigators demonstrated that a similar medium supports human CFU-E as well $(2,3)$. However, another unresolved question which was posed by Iscove et al. (1) concerns the effect of numerous contaminant accessory cells and their products. The presence of BFU-E of diverse maturity might also influence the CFU-E count through the production of metabolic products (4), and a variable interpretation of the classification and count of the erythroid colonies.

It is now possible to obtain highly purified human CFU-E which provide a well-defined experimental system that avoids the effects of additional uncontrolled cells on CFU-E growth and interference with the interpretation of that growth (5). This makes it possible to study the direct effect of hormones and growth factors on CFU-E development and to define the necessary requirements for the growth of these cells. In this paper, these requirements have been studied using the combination of a serum-free medium, highly purified human CFU-E, and the technique of limiting dilution analysis.

\section{Methods}

\section{Blood and marrow}

Peripheral blood and marrow were obtained from normal adult volunteers who had previously signed consent forms approved by the Vanderbilt Committee for the Protection of Human Subjects and the Veterans Administration Research and Development Committee. Approximately $400 \mathrm{ml}$ of peripheral blood or $10 \mathrm{ml}$ of marrow was collected in sodium heparin (Upjohn Co., Kalamazoo, MI) at a final concentration of $20 \mathrm{U} / \mathrm{ml}$.

\section{BFU-E purification}

This method has been previously described (5). In brief, the peripheral blood cells were separated over Ficoll-Hypaque (FH; $1.077 \mathrm{~g} / \mathrm{cm}^{3}$; Pharmacia Fine Chemicals, Piscataway, NJ; Winthrop-Breton Laboratories, NY) at $400 \mathrm{~g}$ for $25 \mathrm{~min}$ at $24^{\circ} \mathrm{C}$. The interface mononuclear FH cells were collected, washed twice with $\alpha$-minimum essential medium ( $\alpha$-MEM) and were resuspended in 50\% Iscove's modified Dulbecco's medium (IMDM) $/ 50 \% \alpha$-MEM (Sigma Chemical Co., St. Louis, MO). The FH cells were incubated with sheep erythrocytes as described previously (5), and nonrosetted cells were separated over FH at $400 \mathrm{~g}$ for $15 \mathrm{~min}$ at $24^{\circ} \mathrm{C}$. These cells were washed twice and surface immunoglobulin-positive cells were depleted by panning with dishes that had been previously coated with affinity-purified sheep anti-

EACA, epsilon aminocaproic acid; EPO, erythropoietin; FH, FicollHypaque; GH, recombinant human growth hormone; GM-CSF, recombinant human granulocyte-macrophage colony-stimulating factor; IGF, insulin-like growth factor; IMDM, Iscove's modified Dulbecco's medium; MC, methylcellulose; rHuEPO, recombinant human erythropoietin; PDGF, platelet-derived growth factor. 
human IgG specific for the $\mathrm{F}(\mathrm{ab})_{2}$ fragment (Cappel Laboratories, Inc., Malvern, PA). The nonadherent cells were collected and incubated overnight in polystyrene flasks, at $37^{\circ} \mathrm{C}$ in a $5 \% \mathrm{CO}_{2}$ atmosphere with $20 \%$ FCS and $10 \%$ giant cell tumor-conditioned medium (Gibco, Grand Island, NY). Nonadherent day 1 cells were suspended at 70 $\times 10^{6} \mathrm{cells} / \mathrm{ml}, 3^{\circ} \mathrm{C}$, in a mixture of four monoclonal antibodies: $25 \mu \mathrm{l}$ of CD11b/OKM $* 1(20 \mu \mathrm{g} / \mathrm{ml}), 25 \mu \mathrm{l}$ of CD2/OKT $* 11(10 \mu \mathrm{g} / \mathrm{ml})$ (Ortho Diagnostic Systems, Inc., Raritan, NJ), $50 \mu \mathrm{l}$ of CD45R/MY 11 , and $50 \mu \mathrm{l}$ of MY 23 to coat granulocytes, monocytes, CFU-granulocyte-macrophage (CFU-GM), $\mathrm{T}$ and $\mathrm{B}$ lymphocytes and natural killer cells (5). After $60 \mathrm{~min}$ the cells were washed three times and were incubated at $4^{\circ} \mathrm{C}$ for $90 \mathrm{~min}$ on plastic tissue culture dishes that had been coated with affinity-purified goat anti-murine IgG (Boerhringer Mannheim Biochemicals, Indianapolis, IN). The antibody-negative, nonadherent cells were then collected for tissue culture.

\section{Culture of $B F U-E$}

Purified BFU-E were cultured at $3 \times 10^{5}$ cells $/ \mathrm{ml}$ in $0.9 \%$ methylcellulose (MC) with $1 \%$ deionized (6) human serum albumin (American Red Cross Blood Service), $10^{-4}$ M 2-mercaptoethanol (Eastman Kodak Co., Rochester, NH), 30\% fetal calf serum (FCS, Hyclone Laboratories, Logan, UT), penicillin at $500 \mathrm{U} / \mathrm{ml}$, streptomycin at 40 $\mu \mathrm{g} / \mathrm{ml}, 10 \%$ giant cell tumor-conditioned medium, and $2 \mathrm{U} / \mathrm{ml}$ of recombinant human erythropoietin (rHuEPO, 10,000 U/mg protein AMGen Biologicals, Thousand Oaks, CA) by the method of Iscove et al. (7). The cells were plated in flat-bottomed, 12-well, tissue culture plates (Linbro, Flow Laboratories Inc., McLean, VA) at $1.0 \mathrm{ml}$ per well and were incubated at $37^{\circ} \mathrm{C}$ in a high-humidity $5 \% \mathrm{CO}_{2}, 95 \%$ air incubator.

\section{CFU-E purification}

After $7 \mathrm{~d}$ of BFU-E culture, the cells that proliferated in MC were collected and washed as previously described (5). Adherent cells were removed as described above. The nonadherent cells were collected and a 2-ml cell suspension was overlaid on $2 \mathrm{ml}$ of $\mathrm{FH}$. After centrifugation at $450 \mathrm{~g}$ for $15 \mathrm{~min}$ at $24^{\circ} \mathrm{C}$, the interface cells (MC FH) were collected and washed three times with $\alpha$-MEM, and resuspended in $50 \%$ IMDM $/ 50 \%$ F-12[HAM] (Sigma Chemical Co.) containing $0.1 \%$ crystalline BSA (nuclease- and protease-free; Calbiochem-Behring Diagnostics, La Jolla, CA) that had been delipidated, deionized, and dialyzed (C-BSA-3D) as described below.

\section{Preparation of bone marrow (BM) cells}

BM cells were diluted with an equal amount of $\alpha$-MEM and separated over $\mathrm{FH}$ at $400 \mathrm{~g}$ for $25 \mathrm{~min}$ at $24^{\circ} \mathrm{C} \mathrm{(8)}$. The interface mononuclear cells (BM FH) were collected, washed three times with $\alpha$-MEM, and were then resuspended in 50\% IMDM/50\% F-12[HAM] containing $0.1 \%$ C-BSA-3D.

\section{Preparation of media}

BSA, transferrin, and lipid suspension were prepared using minor modifications of the methods of Iscove et al. (1). Dextran T40 (Pharmacia, Uppsala, Sweden), $200 \mathrm{mg}$, was dissolved in $200 \mathrm{ml}$ of endotoxin-free, deionized, and distilled water, which was used for all preparations. Activated charcoal (Sigma Chemical Co.), $2 \mathrm{~g}$, was suspended in this solution and kept for $30 \mathrm{~min}$ at room temperature with occasional agitation. Crystalline BSA, $10 \mathrm{~g}$, was added to the suspension and allowed to dissolve without stirring. The $\mathrm{pH}$ was then adjusted to 3.0 by slow dropwise addition of $5 \mathrm{M} \mathrm{HCl}$ with rapid stirring. The mixture was heated to $56^{\circ} \mathrm{C}$ for $30 \mathrm{~min}$ with frequent agitation. Charcoal was then partially removed by centrifugation at $2,700 \mathrm{~g}$ for 30 min. The $\mathrm{pH}$ was adjusted to 5.5 with $1 \mathrm{M} \mathrm{NaOH}$, and the remaining charcoal was removed using 0.8 and $0.45-\mu \mathrm{m}$ Millipore filters (Millipore Corp., Bedford, MA). The solution was deionized by resin AG 501-X8(D) (Bio-Rad Laboratories, Richmond, CA) (6) and concentrated to $50 \mathrm{ml}$ over a Diaflo UM-10 membrane (Amicon Div., W. R. Grace \& Co., Danvers, MA). After dissolving $1.8 \mathrm{~g}$ of IMDM and $0.3 \mathrm{~g}$ of $\mathrm{NaHCO}_{3}$ into the albumin solution, the $\mathrm{pH}$ was adjusted to 7.4 and it was diluted to $100 \mathrm{ml}$ with water $(10 \% \mathrm{wt} / \mathrm{vol})$. The BSA solution was filter-sterilized and dialyzed in 2 liters of IMDM overnight at $3^{\circ} \mathrm{C}$. The C-BSA-3D was filter-sterilized again, stored at $-20^{\circ} \mathrm{C}$, and routinely used for serum-free media. Cohn Fraction V BSA (Armour Pharmaceutical Co., Kankakee, IL; purity $95 \%$ ) was treated by the same procedures as those of C-BSA-3D and used for serum-containing media. In experiments with $\mathrm{L}$-triiodothyronine $\left(\mathrm{T}_{3}\right) 1 \%$ C-BSA-3D, containing $5.7 \times 10^{-11} \mathrm{M} \mathrm{T}_{3}$, was replaced by crystalline BSA (Sigma Chemical Co., essentially fatty acid-free, globulin-free) in which $\mathrm{T}_{3}$ was not measurable.

Human transferrin (iron-saturated, purity $98 \%$, Sigma Chemical Co.), $360 \mathrm{mg}$, was dissolved in $4 \mathrm{ml}$ of IMDM, pH 7.4, and then was totally saturated with $\mathrm{FeCl}_{3}$. A 1.5 -ml solution of $7.9 \mathrm{mM} \mathrm{FeCl}_{3}$ in 1 $\mathrm{mM} \mathrm{HCl}$, was added to the transferrin solution and the mixture was dialyzed in 1 liter of IMDM to remove free iron and preservatives. The solution was then filter-sterilized and the concentration was adjusted to $30 \mathrm{mg} / \mathrm{ml}$ with IMDM before storage at $-70^{\circ} \mathrm{C}$.

Oleic acid (Sigma Chemical Co.), $28 \mathrm{mg}, \mathrm{L}-\alpha$-phosphatidylcholine (Sigma Chemical Co.), $40 \mathrm{mg}$, and cholesterol (Sigma Chemical Co.), $39 \mathrm{mg}$, were dissolved in $0.5 \mathrm{ml}$ of chloroform at room temperature. The solvent was then completely evaporated until no chloroform odor remained, leaving a lipid film on the bottom of the beaker. $50 \mathrm{ml}$ of phosphate-buffered saline (PBS), pH 7.4, containing 1\% C-BSA-3D, was added and the beaker was placed in ice water for sonication at 0.45 $\mathrm{W} / \mathrm{in}^{2}, 60 \mathrm{kHz}$, for $30 \mathrm{~min}$ (Ultrasonic Cleaner, Heat Systems-Ultrasonics, Inc., Plainview, NY). The contents were filtered through Millipore filters of pore-size 0.8 and $0.45 \mu \mathrm{m}$ and stored at $4^{\circ} \mathrm{C}$.

Porcine insulin (26.3 USP U/mg; Calbiochem-Behring Corp.), 20 $\mathrm{mg}$, was completely dissolved in $1 \mathrm{ml} 10 \mathrm{mM} \mathrm{HCl}$ and was centrifuged at $15,300 \mathrm{~g}$ for $4 \mathrm{~min}$ at $4^{\circ} \mathrm{C}$. The supernatant was diluted to $40 \mathrm{ml}$ with IMDM containing $0.3 \%$ C-BSA-3D and was then stored at $-70^{\circ} \mathrm{C} .5$ $\mathrm{ml}$ of recombinant human insulin $(100 \mathrm{U} / \mathrm{ml}, 26 \mathrm{U} / \mathrm{mg}$, Eli Lilly \& Co., Indianapolis, IN) with $0.6 \%$ C-BSA was dialyzed twice with 500 $\mathrm{ml}$ of IMDM at $3^{\circ} \mathrm{C}$ for $12 \mathrm{~h}$ each time and was then centrifuged and stored like the porcine insulin.

rHuEPO (AMGen Biologicals, 10,000 U/mg protein) was dissolved in IMDM containing $0.1 \%$ C-BSA-3D at a concentration of $50 \mathrm{U} / \mathrm{ml}$, and stored at $-20^{\circ} \mathrm{C}$.

Human fibrinogen (grade L, coagulability $90 \%$ of total protein content, KabiVitrum, Stockholm, Sweden), $100 \mathrm{mg}$ protein, was dis-

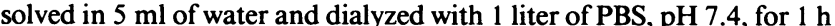
and with 1 liter of $\alpha$-MEM for another $2 \mathrm{~h}$. This solution was filtersterilized and was kept at $24^{\circ} \mathrm{C}$ for use within $24 \mathrm{~h}$.

Thrombin (Parke-Davis, Morris Plains, NJ) was dissolved in $\alpha$-MEM at a concentration of $10 \mathrm{U} / \mathrm{ml}$, filter-sterilized, and stored at $-20^{\circ} \mathrm{C}$. The solution was thawed and diluted to a concentration of 2 $\mathrm{U} / \mathrm{ml}$ with $50 \%$ IMDM $/ 50 \% \mathrm{~F}-12$ [HAM] just before its use.

Aminocaproic acid (EACA) (Elkins-Sinn, Inc., Cherry Hill, NJ) was diluted to a concentration of $100 \mathrm{mM}$ with $\alpha$-MEM, filter-sterilized, and stored at $4^{\circ} \mathrm{C}$.

\section{Culture of $C F U-E$}

Serum-free medium. MC FH cells were plated into $0.5 \mathrm{ml}$ mixture of C-BSA-3D $(10 \mathrm{mg} / \mathrm{ml})$, containing iron-saturated transferrin $(150$ $\mu \mathrm{g} / \mathrm{ml}$ ), lipid suspension (oleic acid, $2.8 \mu \mathrm{g} / \mathrm{ml} ; \mathrm{L}-\alpha$-phosphatidylcholine, $4.0 \mu \mathrm{g} / \mathrm{ml}$, cholesterol, $3.9 \mu \mathrm{g} / \mathrm{ml})$, insulin $(10 \mu \mathrm{g} / \mathrm{ml})$, $\mathrm{rHuEPO}(1$ $\mathrm{U} / \mathrm{ml})$, fibrinogen $(2 \mathrm{mg} / \mathrm{ml})$, thrombin $(0.2 \mathrm{U} / \mathrm{ml})$, EACA $(1.5 \mathrm{mM})$, and $50 \%$ IMDM $/ 50 \%$ F-12[HAM]. In some experiments the above concentration of transferrin and lipid suspension was doubled. The cells were then cultured for $7 \mathrm{~d}$ at a concentration of $500 \mathrm{cells} / \mathrm{ml}$ in 24-well flat-bottomed tissue culture plates (Linbro) at $37^{\circ} \mathrm{C}$ in a highhumidity $5 \% \mathrm{CO}_{2}-95 \%$ air incubator. The clots were fixed and stained with benzidine, and erythroid colony-forming cells which gave rise to colonies of 2 or more hemoglobinized cells were scored as erythroid colony-forming cells, while colonies of $8-49$ cells were scored as CFU-E according to previous criteria $(9,10)$. BM FH cells were cultured in the same serum-free mixture at a concentration of $5 \times 10^{4}$ cells/ml 
Serum-containing medium. C-BSA-3D was replaced by Cohn fraction V BSA and $30 \%$ (vol/vol) FCS was added to a culture medium like that above, but without transferrin, lipid suspension, and insulin. In some experiments FCS was added directly to the mixture prepared for serum-free culture.

\section{Culture of BFU-E}

Serum-free medium. The serum-free medium prepared for CFU-E was supplemented by the addition of 2-mercaptoethanol $\left(5 \times 10^{-5} \mathrm{M}\right)$ and various concentrations of recombinant human interleukin 3 (IL-3) (Genzyme, Boston, MA; $10^{8} \mathrm{CFU} / \mathrm{mg}$ ) and/or recombinant human granulocyte-macrophage colony-stimulating factor (GM-CSF) (Genetics Institute, Cambridge, MA; 50\% desialated, $2.1 \times 10^{7} \mathrm{U} / \mathrm{mg}$ ). The cells were cultured with $2 \mathrm{U} / \mathrm{ml}$ of $\mathrm{rHuEPO}$ for $14 \mathrm{~d}$ and then the clots were fixed and stained with benzidine. Enumeration of BFU-E was performed in accordance with the criteria of Clarke and Hous$\operatorname{man}(8)$.

Serum-containing medium. The cells were plated into a $0.5-\mathrm{ml}$ mixture of Cohn fraction V BSA $(10 \mathrm{mg} / \mathrm{ml})$, that had been delipidated, deionized, and dialyzed as described above, 20\% FCS (vol/vol), $10 \%$ pooled human AB serum (vol/vol), rHuEPO $(2 \mathrm{U} / \mathrm{ml}), 2-\mathrm{mer}$ capthoethanol $\left(5 \times 10^{-5} \mathrm{M}\right)$, fibrinogen $(2 \mathrm{mg} / \mathrm{ml})$, thrombin $(0.2$ $\mathrm{U} / \mathrm{ml}$ ), IL-3 ( $25 \mathrm{U} / \mathrm{ml}$ ), and IMDM, and were then cultured for $14 \mathrm{~d}$.

\section{Specific binding of radioiodinated insulin and insulin-like growth factor I (IGF-I) to CFU-E}

Human insulin, ${ }^{125} \mathrm{I}$-labeled at tyrosine-A14 $(2,013 \mathrm{Ci} / \mathrm{mmol})$, and human recombinant (3-[25I]iodotyrosyl)IGF-I, $\left[\mathrm{Thr}^{59}\right](2,013 \mathrm{Ci} /$ mmol) were purchased from Amersham Corp., Arlington Heights, IL.

Before binding, the cells were incubated with $1 \mathrm{ml}$ of $50 \%$ IMDM $/ 50 \%$ F- 12 [HAM] containing $0.1 \%$ C-BSA-3D, $75 \mu \mathrm{g} / \mathrm{ml}$ ironsaturated transferrin, $10 \mu \mathrm{l} / \mathrm{ml}$ lipid suspension, and $1 \mathrm{U} / \mathrm{ml} \mathrm{rHuEPO}$ for $60 \mathrm{~min}$ at $37^{\circ} \mathrm{C}$ in a high-humidity $5 \% \mathrm{CO}_{2}-95 \%$ air incubator. The cell suspension was then overlaid on $3 \mathrm{ml}$ of $\mathrm{FH}$ and was centrifuged at $600 \mathrm{~g}$ for $15 \mathrm{~min}$ at $24^{\circ} \mathrm{C}$. The interface cells were collected, washed three times with $\alpha$-MEM, and then resuspended in 50\% IMDM $/ 50 \%$ F-12[HAM] containing $0.1 \%$ C-BSA-3D. $100 \mu$ l containing $4 \times 10^{5}$ cells was incubated with $0.66 \mathrm{nM}$ radioiodinated insulin or IGF-I in $1-\mathrm{ml}$ conical tubers (SARSTEDT, Numbrecht, Federal Republic of Germany) for $5 \mathrm{~h}$ at $37^{\circ} \mathrm{C}$ in the above incubator. Replicate tubes had a 5,000-fold concentration of insulin or IGF-I, respectively, to measure nonspecific binding. After this time, ice-cold IMDM containing $0.25 \%$ BSA was added to the tube and $1 \mathrm{ml}$ of the cell suspension was overlaid on $3.5 \mathrm{ml}$ of $10 \%$ BSA/PBS in a $15-\mathrm{ml}$ tube. The tube was centrifuged at $600 \mathrm{~g}$ for $5 \mathrm{~min}$ at $3^{\circ} \mathrm{C}$ and the supernatant was removed at the level of the BSA. The tube wall was washed twice with $4 \mathrm{ml}$ of IMDM and the BSA was removed. The cells were then washed again with $10 \mathrm{ml}$ of IMDM containing $0.25 \%$ BSA. The cells were resuspended in IMDM with $1.0 \%$ BSA at a concentration of $10^{6} / \mathrm{ml}$ and cytocentrifuge (Shandon, Southern Products Ltd., Astmoor, Runcorn, Cheshire, England) preparations were made from $100-\mu \mathrm{l}$ aliquots.

Duplicate cytospin slides were fixed in $2.0 \%$ glutaraldehyde in PBS. Slides were washed three times with PBS, dehydrated through a series of ethanol washes, and allowed to air dry. The slides were dipped in Kodak NTB-2 emulsion (Eastman Kodak Co., Rochester, NY), diluted 1:1 with distilled water, dried, and exposed for $6 \mathrm{wk}$ at $3^{\circ} \mathrm{C}$. Autoradiograms were developed in Kodak D-19 developer diluted 1:1 with distilled water, rinsed briefly in distilled water, and fixed using Kodak fixer. Autoradiograms were washed with running water for 20 min before staining with hematoxylin and eosin. Photomicrographs were taken using Plus-X film and developed in Dialine.

To quantitate the number of cells positive for ${ }^{125} \mathrm{I}$-insulin or ${ }^{125} \mathrm{I}$ IGF-I binding, the following procedure was used. On each slide, the number of grains per cell were counted for 100 cells. More than $95 \%$ of the cells with nonspecifically bound ligand possessed five or fewer grains per cell. Therefore, on the slides containing cells that had total binding of the ligand any cell having six or more grains was considered a positive cell for specific binding. The percent of positive and negative cells was calculated for each of the duplicate slides.

\section{Source and assays for multiple hormones and growth factors}

Hydrocortisone was purchased from Calbiochem-Behring Corp. Testosterone and $\mathrm{T}_{3}$ were purchased from Sigma Chemical Co. Recombinant human IGF-I was purchased from AMGen and recombinant human growth hormone (GH), $2 \mathrm{IU} / \mathrm{mg}$, was purchased from Genetech, Inc., South San Francisco, CA. Human platelet-derived growth factor (PDGF), 312,500 half-maximal $\mathrm{U} / \mathrm{mg}$ protein, and rat insulinlike growth factor II (IGF-II) were purchased from Collaborative Research Inc., Lexington, MA. Hydrocortisone and testosterone were dissolved in absolute ethanol at a concentration of $10 \mathrm{mM}$ and stored at $3^{\circ} \mathrm{C} . \mathrm{T}_{3}$ was dissolved in 1 part $\mathrm{HCl}+2$ parts absolute ethanol at a concentration of $100 \mathrm{mM}$, and then diluted to $10 \mathrm{mM}$ with absolute ethanol, and stored at $3^{\circ} \mathrm{C}$. PDGF, IGF-I, and IGF-II were dissolved in $10 \mathrm{mM} \mathrm{HCl}$ at a concentration of $50 \mu \mathrm{g} / \mathrm{ml}$ and stored at $-70^{\circ} \mathrm{C}$. GH was dissolved in IMDM at a concentration of $10 \mathrm{mg} / \mathrm{ml} \mathrm{just} \mathrm{before} \mathrm{use.}$ Filter-sterilization was avoided for the preparation of these reagents.

Radioimmune assays of diverse hormone concentrations in C-BSA-3D, C-BSA (Sigma Chemical Co.), fibrinogen, thrombin, and transferrin were made by the Vanderbilt Clinical Laboratory. Hydrocortisone was measured by the Coat-A-Count Cortisol procedure of Diagnostic Products Corp., Los Angeles, CA; $\mathrm{T}_{3}$ by the ${ }^{125}$ I-triiodothyronine procedure of Immuchem Corp., Carson, CA; testosterone by the method of Abraham et al. (11); GH by the method of Glick et al. (12); and insulin by the Pharmacia Insulin R1A 100 procedure of Pharmacia Diagnostics, Uppsala, Sweden.

Significance was calculated using the $t$ test (13).

\section{Results}

Growth of CFU-E in serum-free medium. The appropriate concentration of each ingredient of the serum-free medium was determined with dose-response curves and comparison to growth in serum-containing medium (Fig. 1). C-BSA-3D, transferrin, lipid suspension, rHuEP, and insulin were essential for optimal CFU-E growth. Omission of insulin reduced the number of erythroid colonies by $60 \%$ whereas the combination of these ingredients allowed MC FH cells to express the same number of erythroid colonies as those developed in serum-containing cultures. Maximal stimulatory activity of each ingredient was seen at the following concentrations: rHuEPO, $1 \mathrm{U} / \mathrm{ml}$; C-BSA-3D, $10 \mathrm{mg} / \mathrm{ml}$; transferrin, 75 $\mu \mathrm{g} / \mathrm{ml}$; lipid suspension, $5 \mu \mathrm{l} / \mathrm{ml}$ (oleic acid, $2.8 \mu \mathrm{g} / \mathrm{ml} ; \mathrm{L}-\alpha-$ phosphatidylcholine, $4.0 \mu \mathrm{g} / \mathrm{ml}$; cholesterol, $3.9 \mu \mathrm{g} / \mathrm{ml}$ ); and insulin, $10 \mu \mathrm{g} / \mathrm{ml}$. Similar results were also observed when pure rHuEPO (AMGen; 160,000 U/mg protein) was used (data not shown).

Proliferative capacity of erythroid progenitors in serum-free medium. The size of the erythroid colonies that developed in serum-free and serum-containing media was compared as shown in Table I. When MC FH cells were plated in serumfree medium, they expressed the same number of erythroid colony-forming cells as those in serum-containing medium, but the number of CFU-E colonies, consisting of 8-49 cells, was $82 \%$ and greater than the number observed in serum-containing medium $(P<0.001)$. The serum-free medium supported increased proliferative capacity of the erythroid progenitor cells, either through a better nutrient mix or the removal of a serum inhibitor, and was better for CFU-E growth than the serum-containing medium. Almost no colonies of 50 or more cells were observed in either serum-free or serum- 


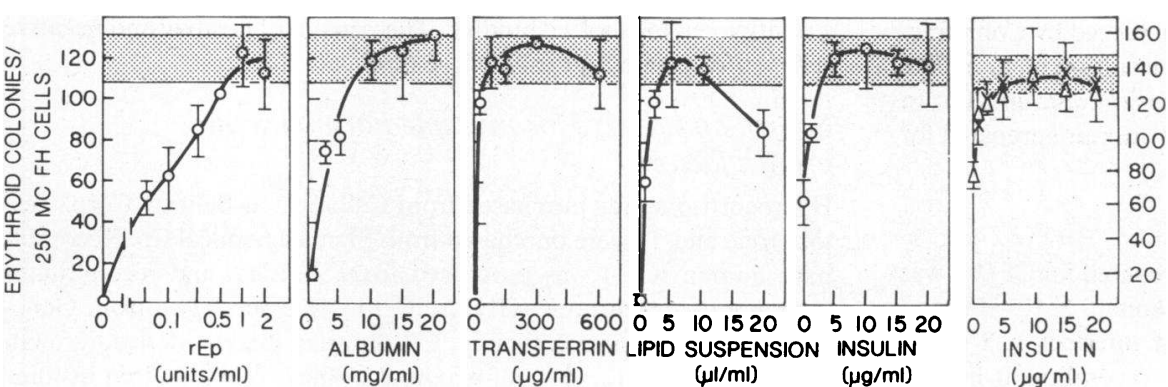

cells were plated in 0.5-ml fibrin clots at a $\mathrm{mg} / \mathrm{ml})$, and thrombin $(0.2 \mathrm{U} / \mathrm{ml})$. MC FH show the mean $\pm \mathrm{SD}$ of triplicates observed in serum-containing medium. In a separate experiment recombinant human insulin $(x)$ was compared to porcine insulin $(\Delta)$ under the same conditions.

containing medium. When MC FH cells were incubated in serum-containing medium to assay for BFU-E, no BFU-E colonies were observed (data not shown) indicating that MC FH cells predominantly consisted of late stage EPO-dependent erythroid progenitor cells.

To examine whether the serum-free medium could support primary culture of bone marrow CFU-E, BM FH cells were plated in serum-free medium. These cells expressed only $61 \%$ of the number of erythroid colonies grown in serum-containing medium. At least half of the decrease in erythroid colony formation occurred with the disappearance of erythroid colonies of $>50$ cells that were present in BM FH cells and not in MC FH cells. These larger colonies, with more proliferative capacity, arise from more immature erythroid progenitor cells such as late BFU-E. Their appearance demonstrates the heterogeneity of BM FH erythroid progenitors and their disappearance in serum-free medium indicates that it is not adequate for more immature erythroid progenitor cells.

Limiting dilution analysis of $C F U-E$ growth. The clonal basis of CFU-E growth was studied using limiting dilution analysis (14). MC FH cells were plated in serum-free or serum-containing medium at a variety of concentrations as indicated in Fig. 2, and the percentage of non-responder wells was plotted against the number of cells per well. Both serumfree and serum-containing medium showed overlapping straight lines through the origin, indicating that both of the culture systems are completely adequate for growth of single
CFU-E and that CFU-E do not require accessory cells for their clonal development. This result also indicates that insulin acts directly on the CFU-E (14).

Effect of IL-3 and/or GM-CSF on erythroid progenitor cell growth. MC FH cells and partially purified blood BFU-E were plated into serum-free medium with various concentrations of IL-3 and/or GM-CSF. As shown in Fig. 3, no effect of IL-3 or GM-CSF on CFU-E growth was observed, whereas IL-3 or GM-CSF markedly enhanced BFU-E growth, the former more than the latter. Addition of GM-CSF to cultures grown in the presence of an appropriate amount of IL-3 did not result in a significant enhancement of colony formation. These results indicate that CFU-E in contrast to BFU-E; do not require IL-3 and GM-CSF for colony development.

Effect of multiple hormones and growth factors on erythroid colony-forming cell development. Using MC FH cells, the effects of hydrocortisone, $T_{3}$, testosterone, PDGF, GH, IGF-I, and IGF-II, which have been reported to enhance or suppress growth of erythroid progenitor cells, were studied in serumfree medium. None of these reagents except IGF-I showed an effect on erythroid colony growth at physiological concentrations, and in the presence of insulin the effect of IGF-I was not apparent (Fig. 4). Because the marked stimulatory effect of IGF-I was only evident in the absence of insulin these experiments were repeated in serum-free medium without insulin. As shown in Fig. 5, none of these hormones, IL-3, or GM-CSF were able to replace insulin, except IGF-I, in providing a

Table I. Proliferative Capacity of Erythroid Colony-forming Cells in Serum-containing and-free Medium

\begin{tabular}{cccccccc}
\hline & & \multicolumn{7}{c}{ Number of cells in erythroid colonies } & E \\
\cline { 3 - 7 } Cells & Serum & $2-4$ & $5-7$ & $8-16$ & $17-49$ & $>50$ & Percentage of control \\
\hline \multirow{3}{*}{ MC FH } & & $\%$ & $\%$ & $\%$ & $\%$ & $\%$ & 100 \\
& $(+)$ & $26 \pm 5$ & $13 \pm 4$ & $53 \pm 10$ & $11 \pm 10$ & $1 \pm 3$ & $103 \pm 5$ \\
BM FH & $(-)$ & $9 \pm 2$ & $8 \pm 1$ & $49 \pm 5$ & $33 \pm 3$ & $1 \pm 1$ & 100 \\
& $(+)$ & $31 \pm 8$ & $9 \pm 3$ & $24 \pm 5$ & $19 \pm 6$ & $22 \pm 6$ & $61 \pm 12$ \\
& $(-)$ & $23 \pm 4$ & $7 \pm 4$ & $53 \pm 6$ & $16 \pm 5$ & $0.4 \pm 0.5$ & \\
\end{tabular}

MC FH cells and BM FH cells were cultured in serum-containing and -free $0.5-\mathrm{ml}$ fibrin clots at a concentration of 500 cells $/ \mathrm{ml}$ and $1 \times 10^{5}$ cells $/ \mathrm{ml}$, respectively. After $7 \mathrm{~d}$ of culture, clots were fixed and stained by benzidine, and the number of hemoglobin-containing cells per colony was counted. Mean values \pm SD for three experiments are shown. The number of erythroid colonies observed in serum-free medium was compared with the number in serum-containing medium, and the data expressed as $\%( \pm \mathrm{SD})$ of the latter. The absolute number of erythroid colony-forming cells observed in serum-containing medium in these three experiments was $137 \pm 35$ per $250 \mathrm{MC}$ FH cells and $522 \pm 212$ per $5 \times 10^{4} \mathrm{BM}$ FH cells. 


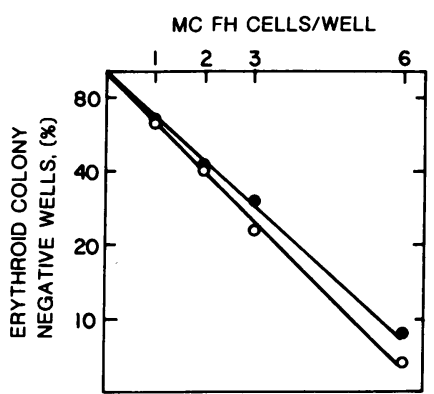

Figure 2. Limiting dilution analysis of CFU-E growth. MC FH cells were suspended in serum-containing $(\bullet)$ and serum-free $(0)$ medium at concentrations of $20,40,60$, and $120 \mathrm{cells} / \mathrm{ml}$. Aliquots of $50 \mu \mathrm{l}$ were plated into 96-well tissue culture flat bottom plates. After $7 \mathrm{~d}$ of incubation, the clots were fixed and stained by benzidine, and the number of clots in which erythroid colonies did not develop were counted as erythroid colony-negative wells. This was plotted against the number of MC FH cells plated into the wells. Each point represents the values obtained from 60 wells.

serum-free medium that was equivalent to serum-containing medium in supporting erythroid colony growth.

Since the extracted biological components of the serumfree medium might be contaminated with diverse hormones, the concentration of hydrocortisone, $\mathrm{T}_{3}$, testosterone, $\mathrm{GH}$, and insulin in these ingredients were measured by radioimmunoassay and in all cases the calculated maximum concentrations in the serum-free medium were $<1 \%$ of the concentrations in normal human serum.

Effect of insulin and IGF-I on CFU-E development. Using MC FH cells, the relationship of the concentration of insulin and IGF-I on erythroid colony growth was analyzed (Fig. 6). Only $46 \%$ of the maximum erythroid colony number was observed in the absence of insulin and IGF-I, but with increasing concentrations of insulin or IGF-I, the number of colonies

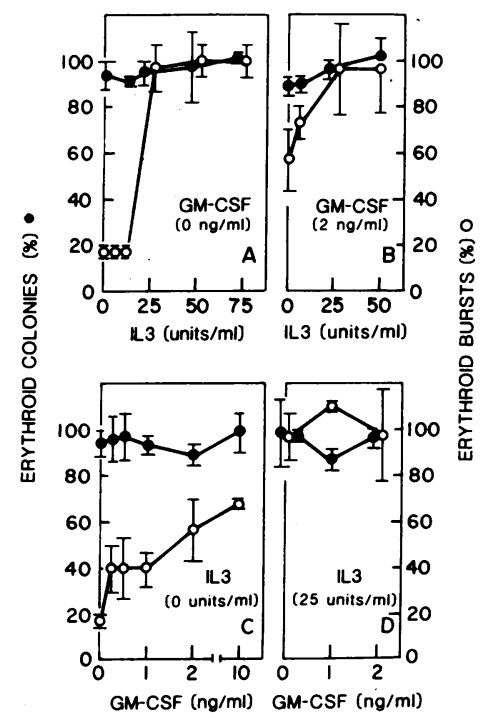

Figure 3. Effect of IL-3 and/or GM-CSF on erythroid progenitor cells. MC FH cells were cultured in serum-free medium at a concentration of 500 cells/ $\mathrm{ml}$ in the presence of various concentrations of IL-3 and/or GM-CSF. After $7 \mathrm{~d}$ of culture, clots were fixed and stained with benzidine, and the number of erythroid colonies was counted. Cell aliquots were also plated into serum-containing medium without IL-3 and GM-CSF. Each value is the mean $\pm \mathrm{SD}$ of triplicates and is expressed as a percentage of the value obtained in serum-containing cultures which gave rise to $151 \pm 12$ erythroid colonies/250 MC FH cells in each clot. For BFU-E growth the serum-free medium was supplemented with $5 \times 10^{-5} \mathrm{M}$ 2-mercaptoethanol, and BFU-E, partially purified to $0.4 \%$ (5), were cultured at a concentration of $1.5 \times$ $10^{4}$ cells $/ \mathrm{ml}$ in the presence of various concentrations of IL-3 and/or GM-CSF. After $14 \mathrm{~d}$ of culture, clots were fixed and stained with benzidine, and the number of erythroid bursts was counted. Cell aliquots were also plated into serum-containing medium with $25 \mathrm{U} / \mathrm{ml}$ of IL-3. Each value is the mean \pm SD of triplicates and is expressed as a percentage of the value obtained by serum-containing cultures which gave rise to $30 \pm 3$ BFU-E/7,500 cells in each clot.
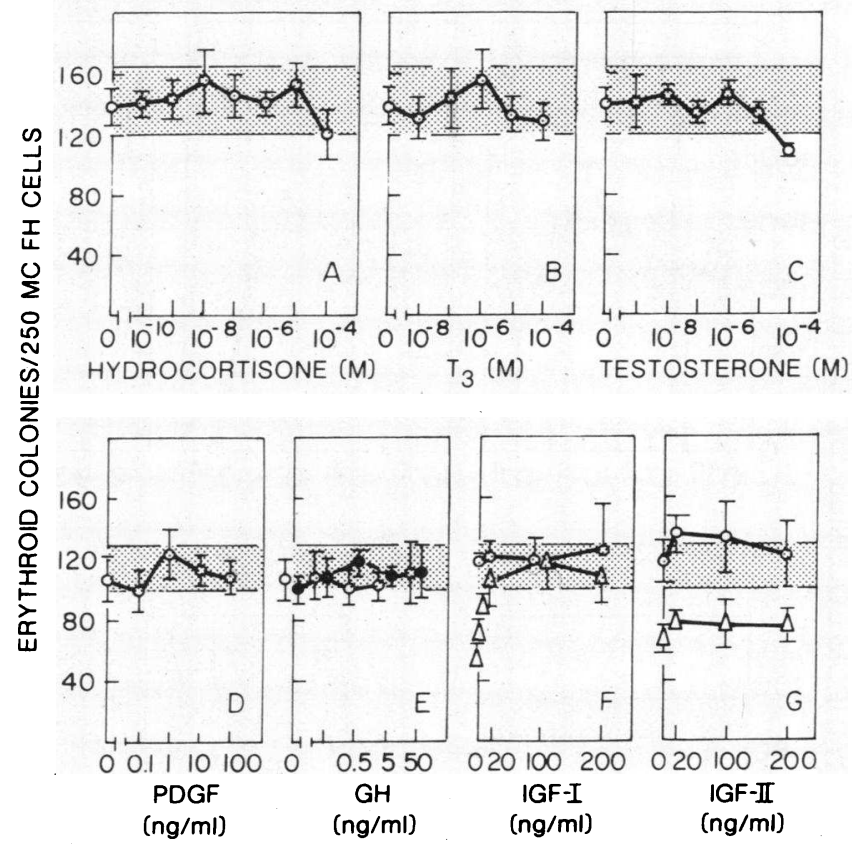

Figure 4. Effect of a variety of hormones and growth factors on erythroid colony-forming cell growth in standard serum-free medium which contained insulin $(10 \mu \mathrm{g} / \mathrm{ml})$. MC FH cells were plated in triplicate and each value represents the mean \pm SD $(O)$. In some experiments, $10 \mathrm{ng} / \mathrm{ml}$ IGF-I was added $(\bullet)(E)$, whereas in others insulin was omitted from the culture medium $(\Delta)(F, G)$. Shaded areas show the mean $\pm \mathrm{SD}$ of triplicates observed in serum-containing cultures. This figure is a composite of two individual experiments $(A-C$ and $D-G)$.

with eight or more cells increased and full erythroid colony development was observed at a concentration of $10 \mu \mathrm{g} / \mathrm{ml}$ of insulin or $100 \mathrm{ng} / \mathrm{ml}$ of IGF-I. Significant increases in the number of erythroid colonies were seen at $1 \mathrm{ng} / \mathrm{ml}$ of insulin or at $1.56 \mathrm{ng} / \mathrm{ml}$ of IGF-I, which are within the physiological range, and small concentrations of insulin significantly enhanced the effect of small concentrations of IGF-I. Although CFU-E respond to both insulin and IGF-I when small physiological concentrations are present, and reach normal growth potential within a range of normal serum concentrations of IGF-I, 100-fold greater concentrations of insulin, in the pharmacologic range, are necessary to equal this effect. No colonies formed in the absence of added rHuEPO.

We also performed limiting dilution analysis of $\mathrm{MC} \mathrm{FH}$ cells in serum-free medium without insulin, but with $100 \mathrm{ng} / \mathrm{ml}$ of IGF-I, to determine if the IGF-I is acting directly on the CFU-E. This experiment demonstrated a single straight line through the origin, indicating that the effect of IGF-I on CFU-E growth is a direct effect on these cells and does not occur through an effect on accessory cells (Fig. 7). Although the number of CFU-E was slightly less than with serum-containing medium a wide variety of subsequent experiments have repeatedly confirmed that the effect with $100 \mathrm{ng} / \mathrm{ml}$ of IGF-I is not significantly different than the effect with serum-containing medium. Autoradiography confirmed direct specific binding of ${ }^{125}$ I-insulin and ${ }^{125}$ I-IGF-I to the CFU-E (Fig. 8).

\section{Discussion}

We improved the purity of three specific factors that relate to CFU-E growth and development. First, we developed a 


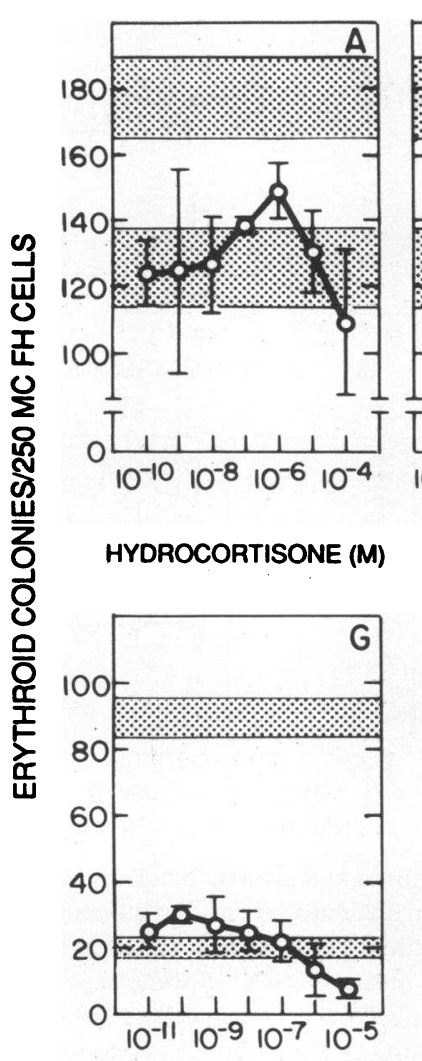

TRIIODOTHYRONINE (M)

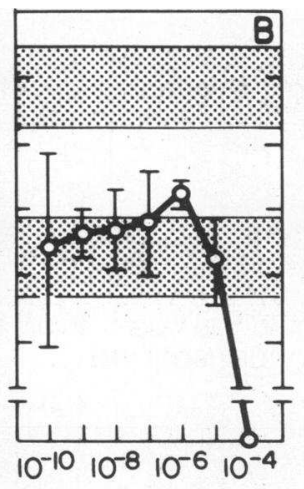

TESTOSTERONE (M)

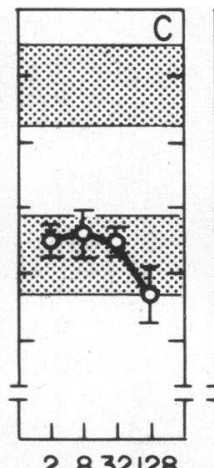

2832128

PDGF $\left(M \times 10^{-11}\right)$

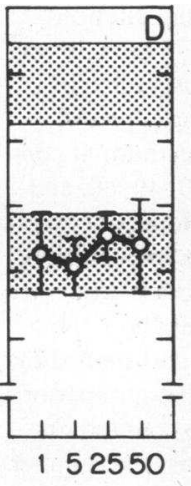

$\mathrm{GH}\left(\mathrm{M} \times 10^{-7}\right)$

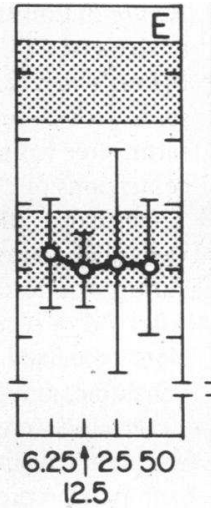

IL3 (U/ml)

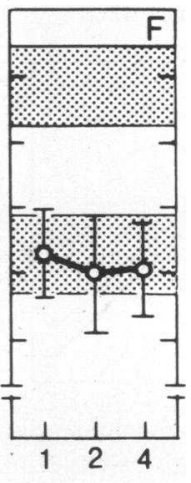

GM-CSF (ng/ml)

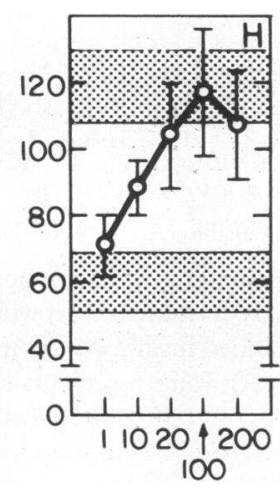

IGF-I (ng/ml)

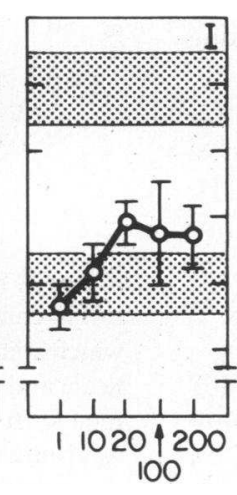

IGF-\|l (ng/ml)

Figure 5. Effect of a variety of hormones and growth factors on erythroid colony-forming cell growth in serum-free medium without insulin. MC FH cells were plated in triplicate and each value represents the mean \pm SD of triplicates. Upper shaded area shows the mean \pm SD of erythroid colonies in serum-containing cultures, while lower shaded area shows the mean \pm SD of erythroid colonies in serum-free cultures without insulin. The figure is composed of three individual experiments $(A-F, G$, and $H$ and $I)$.

serum-free culture system that supports human CFU-E growth with the same plating efficiency as serum-containing systems and even enhances erythroid progenitor cell proliferation. This

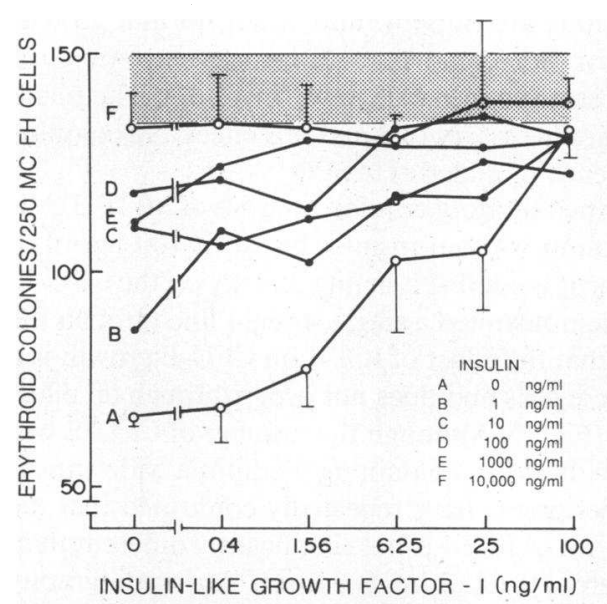

Figure 6. Effect of increasing concentrations of IGF-I and/or insulin on CFU-E growth. MC FH cells were cultured in serum-free medium with various concentrations of IGF-I and/or insulin for $7 \mathrm{~d}$. Each value is the mean of triplicates $(\bullet)$ and for $A$ (absence of insulin) and $F$ (addition of $10 \mu \mathrm{g} / \mathrm{ml}$ insulin) $\pm \mathrm{SD}(0)$. Shaded area shows the mean $\pm \mathrm{SD}$ of triplicates from serum-containing cultures. made it possible to reduce inhibitory and/or stimulatory effects of undefined factors present in the serum, and to see complete effects of added hormones, which might be obscured by high baseline serum concentrations. Secondly, erythroid progenitor cells were highly purified to avoid the effects of nonerythroid cells which produce various growth factors, and metabolites that might influence CFU-E growth (15-18). Thirdly, the presence of a single population of CFU-E, without

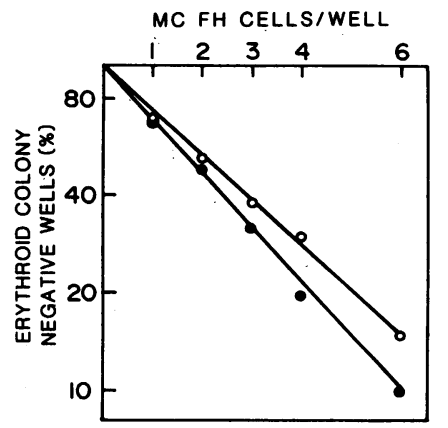

Figure 7. Limiting dilution analysis of CFU-E growth in serum-free medium with IGF-I. MC FH cells, at concentrations of $20,40,60$, and 120 cells $/ \mathrm{ml}$, were suspended in serum-free medium without insulin, but with the addition of $100 \mathrm{ng} / \mathrm{ml}$ of IGF-1 (o), or in serum-containing medium (๑). Aliquots of $50 \mu \mathrm{l}$ were plated into 96-well tissue culture flat-bottomed plates. After $7 \mathrm{~d}$ of incubation, clots were fixed and stained by benzidine, and the number of clots in which erythroid colonies did not grow was counted as erythroid colony-negative wells. This was plotted against the number of MC FH cells plated into the wells. Each point represents the value obtained from 60 wells. 

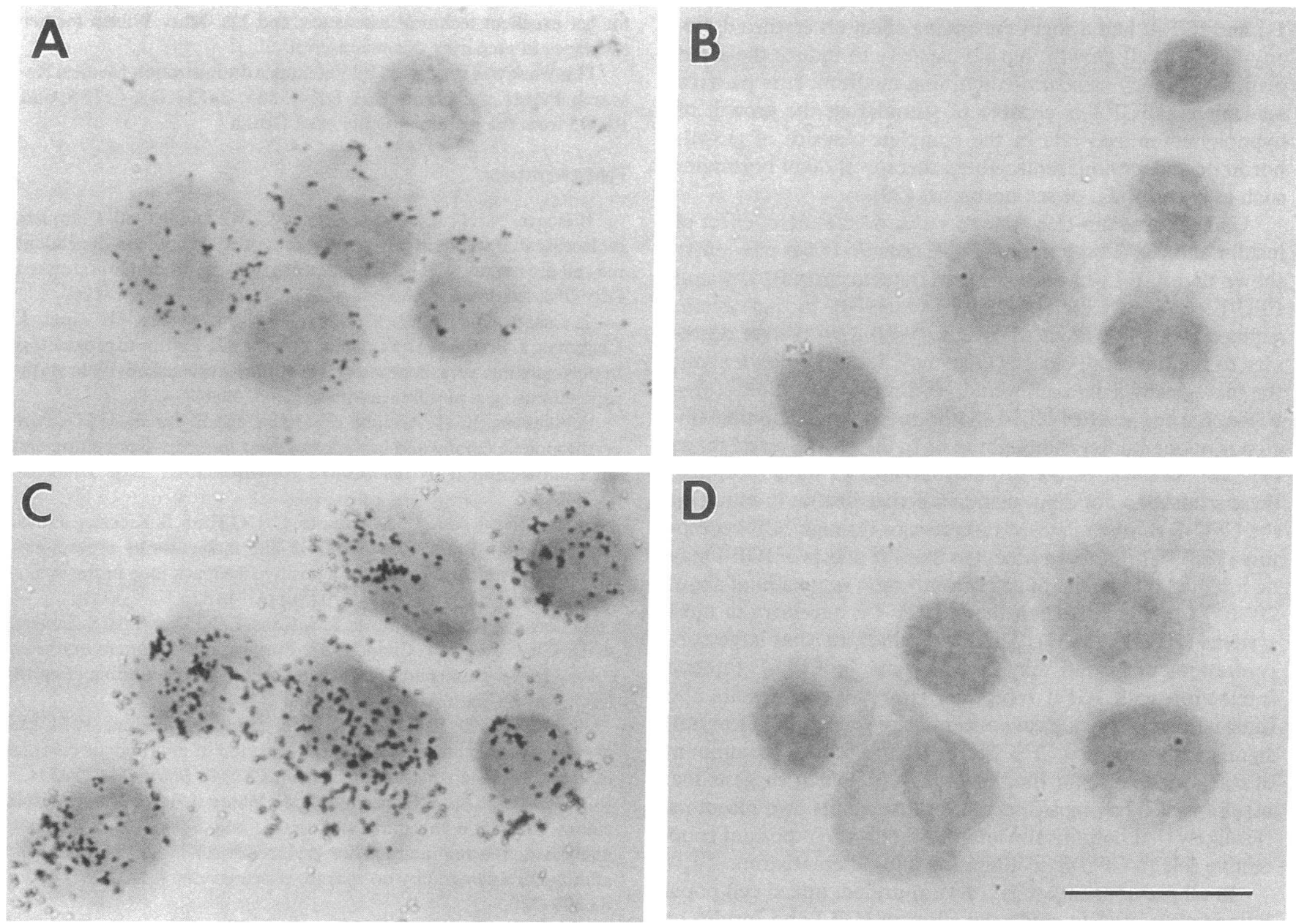

Figure 8. $(A)$ Total and $(B)$ nonspecific ${ }^{125}$ I-insulin binding and $(C)$ total and $(D)$ nonspecific ${ }^{125}$ I-IGF-I binding to human CFU-E. The percentage of cells positive for ${ }^{125}$ I-insulin specific binding was $70-78 \%$ whereas $81-83 \%$ were positive for ${ }^{125}$ I-IGF-I binding. CFU-E were $48 \pm 5 \%$ of the cells. Bar, $20 \mu \mathrm{m}$.

BFU-E, made the evaluation and interpretation of effects of erythropoietic factors more reliable and precise and removed the possible production of other growth factors by additional erythroid cells (4).

In our initial studies, we demonstrated the relative effect of a variety of nutrients on the growth of human CFU-E by their individual dose response curves in serum-free medium. The cloning efficiency is sharply affected by the removal of BSA, lipids, or transferrin. It has been reported that charcoal treatment of BSA reduces the capacity of BSA to sustain erythroid differentiation in vitro (19), and we encountered the same phenomenon. We do not know the precise reason for this, but the problem was completely resolved by changing the medium from IMDM alone to a mixture of IMDM and F-12[HAM]. Omission of insulin led to a $54 \%$ reduction of cloning efficiency and almost no erythroid colonies of eight or more cells. The dose-response curve of rHuEPO in the presence of insulin was like that of serum-containing cultures (5), and despite the addition of insulin and/or IGF-I, no erythroid colonies were seen in the absence of rHuEPO. Thus, our studies indicate that both insulin and IGF-I do not act like EPO since they do not stimulate CFU-E in vitro without the presence of the primary regulator of erythropoiesis. This is in contrast to the studies of Kurtz et al. $(20,21)$ who observed that murine bone marrow and fetal liver CFU-E responded to IGF-I or insulin in a serum-free medium without the presence of EPO, but with a dose-response curve like that of EPO. It is possible that murine CFU-E have different requirements than human CFU-E, but additional possibilities for this difference include the stimulation of adjacent accessory cells to produce other factors that affect the proliferation and differentiation of these cells when they are in a mixed population.

An enhancing effect of hydrocortisone (22), $T_{3}(23)$, testosterone (24), PDGF (25), GH (26), and IGF-II (27) on CFU-E development has been reported. In this investigation, however, we could not detect a significant effect of these hormones or growth factors by repeated experiments. The difference in our results could be explained, in part, by the difference in the cell populations that were tested. In our system, the cells have been highly purified and maturity has been predominantly synchronized to the level of the CFU-E. Therefore, if the effect of a hormone was mediated through accessory cells it might be difficult to detect and if these factors acted mainly on immature erythroid progenitors, no effect would be seen in our system. The enhancing effect of $T_{3}$ on human BFU-E growth has indeed been shown to occur through the release of erythropoietic growth factors by bone marrow accessory cells (28). In the absence of insulin and IGF-I, hydrocortisone, testosterone, 
$T_{3}$, and IGF-II had a slight enhancing effect on erythroid colony-forming cell growth, but no capacity to induce the same plating efficiency as serum-containing medium. It is perhaps relevant that IGF-I is capable of stimulating the growth of hypophysectomized rats in the complete absence of growth hormone and without replacement therapy of other hormones such as cortisol, $\mathrm{T}_{3}$, or sex hormones (29).

Using this serum-free system, we showed a direct effect of insulin and IGF-I on human CFU-E growth. It was previously shown that IGF-I stimulates human bone marrow BFU-E and CFU-E erythroid differentiation in vitro (30). In our system, supraphysiological levels of insulin $(5-10 \mu \mathrm{g} / \mathrm{ml})$ were necessary to maintain full cloning efficiency. Little is known about the biologically active, unbound, serum concentration of free IGF-I, but the level of IGF-I that induced a high cloning effciency in our studies is thought to be in the physiological range $(31,32)$. Because of the cross-reactivities to their receptors, these studies do not demonstrate whether insulin is acting on the CFU-E through its own receptors or through IGF-I receptors $(33,34)$. It has been accepted that the effects of IGF-I may be initiated by insulin, but a concentration of insulin of about 20-100 times greater than that of IGF-I is necessary in most systems $(20,21,35-37)$. This would indicate that large concentrations of insulin may be acting on the CFU-E through interaction with IGF-I receptors. However, our results also indicate that physiological concentrations of insulin $(1 \mathrm{ng} / \mathrm{ml})$ significantly enhance CFU-E growth and reduce the amount of IGF-I necessary for that effect (Fig. 6), which suggests that insulin is also having a direct effect through its own receptors. It is likely that both insulin and IGF-I play an important cooperative role in CFU-E proliferation and differentiation.

In all previous investigations unpurified, mixed cell populations were used to study the effect of IGF-I and insulin on erythroid progenitor cells $(3,20,21,27,30,38,39)$. Even though our CFU-E were purified to $30-60 \%$ of the cell population the effects of added hormones could still occur through a stimulation of the remaining contaminant cells. For this reason we applied the technique of limiting dilution analysis to identify the presence an accessory cell mechanism. When the number of MC FH cells in each serum-free well with IGF-I or insulin was plotted against the logarithm of the percentage of erythroid colony-negative wells, a straight line through the origin was apparent indicating that clonal growth was unaffected by the presence of additional cells and only dependent on the CFU-E itself. If the effect of the added hormone had occurred through an effect on accessory cells an increasing frequency of erythroid colonies would have been noted. The present limiting dilution studies, which show a single hit curve, indicate that a single cell population is involved and that IGF-I and insulin act directly on the CFU-E.

In conclusion, we have found that human CFU-E do not require accessory cells, but do require IGF-I and/or insulin, as well as EPO, for erythroid development. IGF-I and/or insulin are essential for full human CFU-E development and their effects are direct whereas IL-3 and GM-CSF had no effect on CFU-E growth and development.

\section{Acknowledgments}

The authors thank Dr. Curt I. Civin for his generous gift of CD45R/My 11 and MY 23, without which this work would not be possible; Steven Clark and Genetics Institute for supplying GM-CSF; Ms. Sharon Horn for her excellent technical assistance; and Ms. Mary Wilson for her assistance in preparing this manuscript.

This work was supported by Veterans Administration Medical Research Funds and grants R01 DK-15555, 2 T32 DK-07186, and RR-95 from the National Institutes of Health.

\section{References}

1. Iscove, N. N., L. J. Guilbert, and C. Weyman. 1980. Complete replacement of serum in primary cultures of erythropoietin-dependent red cell precursors (CFU-E) by albumin, transferrin, iron, unsaturated fatty acid, lecithin and cholesterol. Exp. Cell Res. 126:121-126.

2. Casadevall, N., W. Vainchenker, C. Lacombe, G. Vinci, J. Chapman, J. Breton-Gorius, and B. Varet. 1982. Erythroid progenitors in polycythemia vera: demonstration of their hypersensitivity to erythropoietin using serum free cultures. Blood. 59:447-451.

3. Akahane, K., T. Arinobu, A. Urabe, and F. Takaku. 1987. Pure erythropoietic colony and burst formations in serum-free culture and their enhancement by insulin-like growth factor I. Exp. Hematol. 15:797-802.

4. Sytkowski, A. J., G. A. Vanases, C. J. O'Hara, S. Kreczka, and N. Dainiak. 1987. Production of PDGF-like molecules by normal erythroid cells in vivo: evidence for a positive feedback loop in the modulation of erythropoiesis. Blood. 70 (Suppl. 1):187a.

5. Sawada, K., S. B. Krantz, J. S. Kans, E. N. Dessypris, S. Sawyer, A. D. Glick and C. I. Civin. 1987. Purification of human erythroid colony-forming units and demonstration of specific binding of erythropoietin. J. Clin. Invest. 80:357-366.

6. McLeod, D. L., M. M. Shreeve, and A. A. Axelrad. 1974. Improved plasma culture system for production of erythrocytic colonies in vitro. Quantitative assay method for CFU-E. Blood. 44:517-534.

7. Iscove, N. N., F. Sieber, and K. H. Winterhalter. 1974. Erythroid colony formation in cultures of mouse and human bone marrow: analysis of the requirement for erythropoietin by gel filtration and affinity chromatography on agarose-concanavalin A. J. Cell. Physiol. 83:309-320.

8. Clarke, B. J., and D. Housman. 1977. Characterization of an erythroid precursor cell of high proliferative capacity in normal human peripheral blood. Proc. Natl. Acad. Sci. USA. 74:1 105-1109.

9. Ogawa, M., M. D. MacEachern, and L. Avila. 1977. Human marrow erythropoiesis in culture. II. Heterogeneity in the morphology, time course of colony formation, and sedimentation velocities of the colony-forming cells. Am. J. Hematol. 3:29-36.

10. Eaves, A. C., and C. J. Eaves. 1984. Erythropoiesis in culture. Clin. Haematol. 13:371-391.

11. Abraham, G. E., F. S. Manlimos, and R. Garza. 1977. Radioimmunoassay of steroids. In Clinical and Biochemical Analysis. Handbook of Radioimmunoassay. Volume 5. G. E. Abraham, editor. Marcel Dekker, Inc., New York. 591-656.

12. Glick, S. M., J. Roth, R. S. Yalow, and S. A. Berson. 1963. Immunoassay of human growth hormone in plasma. Nature (Lond.). 199:784-787.

13. Snedecor, G. W., and W. G. Cochran. 1967. Statistical Methods. 6th edition. Iowa State University Press, Ames, IA.

14. Lefkovits, I., and H. Waldman. 1984. Limiting dilution analysis of the cells of immune system. I. The clonal basis of the immune response. Immunol. Today. 5:265-268.

15. Golde, D. W., and M. J. Cline. 1972. Identification of the colony-stimulating cell in human peripheral blood. J. Clin. Invest. 51:2981-2983.

16. Nathan, D. G., L. Chess, D. G. Hillman, B. Clarke, J. Breard, E. Merler, and D. E. Housman. 1978. Human erythroid burst-forming unit: T-cell requirement for proliferation in vitro. J. Exp. Med. 147:324-339.

17. Kaushansky, K., N. Lin, and J. W. Adamson. 1988. Interleukin 1 stimulates fibroblasts to synthesize granulocyte-macrophage and granulocyte colony-stimulating factors. J. Clin. Invest. 81:92-97. 
18. Lindemann, A., D. Riedel, W. Oster, S. C. Meuer, D. Blohm R. H. Mertelsmann, and F. Herrmann. 1988. Granulocyte/macrophage colony-stimulating factor induces interleukin 1 production by human polymorphonuclear neutrophils. J. Immunol. 140:837-839.

19. Stewart, S., B. Zhu, and A. Axelrad. 1984. A "serum-free" medium for the production of erythropoietic bursts by murine bone marrow cells. Exp. Hematol. 12:309-318.

20. Kurtz, A., W. Jelkmann, and C. Bauer. 1982. A new candidate for the regulation of erythropoiesis. Insulin-like growth factor I. FEBS (Fed. Eur. Biochem. Soc.) Lett. 149:105-108.

21. Kurtz, A., W. Jelkmann, and C. Bauer. 1983. Insulin stimulates erythroid colony-formation independently of erythropoietin. $\mathrm{Br}$. $J$. Haematol. 53:311-316.

22. King, D. J., M. Koekebakker, and R. D. Barr. 1987. Modulation of human erythropoiesis by hydrocortisone in vitro. Eur. J. Haematol. 38:137-140.

23. Golde, D. W., N. Bersch, I. J. Choppa, and M. J. Cline. 1977. Thyroid hormones stimulate erythropoiesis in vitro. Br. J. Haematol. 37:173-177.

24. Dainiak, N., R. Hoffman, A. K. Ritchey, V. Floyd, and M. Callahan. 1980. In vitro steroid sensitivity testing: a possible means to predict response to therapy in primary hypoproliferative anemia. $\mathrm{Am}$. J. Hematol. 9:401-412.

25. Daniak, N., G. Davies, M. Kalmanti, J. Lawler, and V. Kulkarni. 1983. Platelet-derived growth factor promotes proliferation of erythropoietic progenitor cells in vitro. J. Clin. Invest. 71:1206-1214.

26. Golde, D. W., N. Bersch, and C. Haoli. 1977. Growth hormone: species-specific stimulation of erythropoiesis in vitro. Science (Wash. DC). 196:1112-1113.

27. Daniak, N., and S. Kreczko. 1985. Interactions of insulin, insulin-like growth factor II, and platelet-derived growth factor in erythropoietic culture. J. Clin. Invest. 76:1237-1242.

28. Dainiak, N., D. Sutter, and S. Kreczko. 1986. L-triiodothyronine augments erythropoietic growth factor release from peripheral blood and bone marrow leukocytes. Blood. 68:1289-1297.

29. Schoenle, E., J. Zapf, R. E. Humbel, and E. R. Froesch. 1982. Insulin-like growth factor I stimulates growth in hypophysectomized rats. Nature (Lond.). 296:252-253.
30. Claustres, M., P. Chatelain, and C. Sultan. 1987. Insulin-like growth factor I stimulates human erythroid colony formation in vitro. J. Clin. Endocrinol. Metab. 65:78-82.

31. Zapf, J., E. R. Froesch, and R. E. Humbel. 1981. The insulinlike growth factors (IGF) of human serum: chemical and biological characterization and aspects of their possible physiological role. Curr. Top. Cell. Regul. 19:257-309.

32. Zapf, J., H. Walter, and E. R. Froesch. 1981. Radioimmunological determination of insulin like growth factors I and II in normal subjects and in patients with growth disorders and extrapancreatic tumor hypoglycemia. J. Clin. Invest. 68:1321-1330.

33. Zapf, J., E. Schoenle, and E. R. Froesch. 1978. Insulin-like growth factors I and II: Some biological actions and receptor binding characteristics of two purified constituents of nonsuppressible insulinlike activity of human serum. Eur. J. Biochem. 87:285-296.

34. Rechler, M. M., J. Zapf, S. P. Nissley, E. R. Froesch, A. C. Moses, J. M. Podskolny, E. E. Schilling, and R. E. Humbel. 1980. Interactions of insulin-like growth factor I and II and multiplicationstimulating activity with receptors and serum carrier proteins. Endocrinology. 107:1451-1459.

35. Morell, B., and E. R. Froesch. 1973. Fibroblasts as an experimental tool in metabolic and hormone studies. II. Effects of insulin and nonsuppressible insulin-like activity (NSILA-S) on fibroblasts in culture. Eur. J. Clin. Invest. 3:119-123.

36. Schmid, C., T. Steiner, and E. R. Froesch. 1983. Insulin-like growth factors stimulate synthesis of nucleic acid and glycogen in cultured calvaria cells. Calcif. Tissue Int. 35:578-585.

37. Schmid, C., T. Steiner, and E. R. Froesch. 1983. Preferential enhancement of myoblast differentiation by insulin-like growth factors (IFG-I and IFG-II) in primary cultures of chicken embryonic cells. FEBS (Fed. Eur. Biochem. Soc.) Lett. 161:117-121.

38. Bersch, N., J. E. Groopman, and D. W. Golde. 1982. Natural and biosynthetic insulin stimulates the growth of human erythroid progenitors in vitro. J. Clin. Endocrinol. Metab. 55:1209-1211.

39. Perrine, S. P., M. F. Greene, P. D. K. Lee, R. A. Cohen, and D. V. Faller. 1986. Insulin stimulates cord blood erythroid progenitor growth: evidence for an aetiological role in neonatal polycythaemia. Br. J. Haematol. 64:503-511. 